\title{
The New Faces of the Historical Novel
}

\author{
As novas fisionomias do romance histórico
}

\author{
Felipe Charbel a \\ E-mail: fcharbel@gmail.com \\ https://orcid.org/0000-0002-9836-515X (D)
}

\section{ABSTRACT}

This article analyzes the problem of referentiality in the historical novel, based on a comparison between its classic and contemporary forms. The first section addresses the "mixture of history and invention" that, following Alessandro Manzoni, was the foremost characteristic of the realist historical novel. The next section discusses how the meta-historical novel of the second half of the 20th century - for example, Disgrace (J. M. Coetzee) and El entenado (Juan José Saer)eclipsed the problem of referentiality by assuming that the historical novel should operate by its own procedures, and not those of history. The following sections discuss the referential turn in 21st century literary narratives, focusing on three novels: El material humano, by Rodrigo Rey Rosa; K. Relato de uma busca, by Bernardo Kucinski, and Jan Karski, by Yannick Haenel. The article concludes that the inversion of these two poles-from non-referentiality to the predominance of referentiality-is an unexpected facet of the elasticity of the concept (and practice) of fiction, which by denying itself ultimately enriches itself.

\section{PALAVRAS-CHAVE}

Historical novel; Fiction; Historicity

\section{RESUMO}

O artigo discute a questão da referencialidade no romance histórico, a partir da comparação entre sua forma clássica e suas formas contemporâneas. A primeira seção trata da "composição mista de história e invenção" que, segundo Alessandro Manzoni, foi o principal traço do romance histórico realista. Na seção seguinte, discute-se como o romance meta-histórico da segunda metade do século XX - casos de Disgrace (J. M. Coetzee) e El entenado (Juan José Saer), eclipsa o problema da referencialidade, com a pressuposição de que o romance histórico deve operar nos termos dos seus próprios procedimentos, e não nos da história. Nas seções seguintes, o foco se volta para a guinada referencial que marca boa parte das narrativas literárias do século XXI. Três romances são discutidos a partir dessa chave de leitura: El material humano, de Rodrigo Rey Rosa; K. Relato de uma busca, de Bernardo Kucinski; e Jan Karski, de Yannick Haenel. O que se argumenta é que a inversão de polos - da não referencialidade à tendência referencial, é uma faceta inesperada da elasticidade do conceito e da prática da ficção, que, ao negar a si mesma, termina enriquecendo o seu próprio jogo.

\section{KEYWORDS}

Romance histórico; Ficção; Historicidade 


\section{Referentiality in the Realist Historical Novel}

One of the unmistakable characteristics of the realist historical novel, particularly the "classic historical novel" of the $19^{\text {th }}$ century, was its mixture of referentiality and nonreferentiality in the construction of the narrative. Referential texts, following Philippe Lejeune's (2014, p. 43) definition, "propose to provide information about a 'reality' external to the text, thus submitting [themselves] to a process of verification." Since both are "verifiable and incomplete" (COHN 1999, p. 16), referential texts are never closed: it is always possible to contest their accuracy, refute arguments, and suggest new approaches, something that does not happen with non-referential texts, which by nature are "unverifiable and complete."

It is not that fictional narratives cannot refer to external reality, but rather that they don't have to. A novel like Charles Dickens's David Copperfield uses details from both mid-19 $19^{\text {th }}$ century English social life and the author's own biography. Nevertheless, the events narrated in the story cannot be declared to be true or false; rather, what is at play is a resignification of an experience that involves rearranging, selecting, and mixing materials that originate in a variety of "contextual systems" (ISER 1996, p. 16). The realist historical novel, on the other hand, was firmly anchored in concrete historical dynamics. The goal was to transpose onto a fictional universe situations and characters with historical existence, not only through incorporating similarities or resemblances with a reality external to the text, but also recreating the historical past in narrative form (HELLER 2011, p. 89). The mixture of real and invented characters, the entanglement of historically authentic situations with others made up by the author, linguistic and historical anachronisms, the co-existence of the factually verifiable with artistic license: these are some of the peculiarities of the historical novel that even today, when its popularity is lower than it once was, allow us to differentiate it from other types of realist novels, like the Bildungsroman or the Brazilian urban novels. 
In a 1930 s essay that remains a reference for those who study the topic, Györg Lukács argues that the historical novel does not possess sufficiently exclusive formal characteristics to be distinguishable from the realist novel. Rather, its uniqueness lies in the "specific tasks" that result from combining fiction with history, tasks that not only condition, but also stimulate the imagination. The first of these "tasks" is verisimilitude (the "it could have happened" of the action depicted, without being forced to strictly correspond to what happened). The second involves the historicity of the representation of the past. "What matters for the historical novel," Lukács writes (2011, p. 62), "is to evince, through fictional means, the existence, the ithappened-just-this-way of historical events and figures."

The historical novel gives form to History and reveals the connection between past and present. It thus constitutes a narrative genre that demands a sophisticated understanding of history on the part of the author, besides the ability to discern the decisive conflicts of yesterday and today. As a result, the issue of referentiality does not necessarily present itself, in the realist historical novel, as a dilemma concerning the correspondence or non-correspondence to concrete facts of the material narrated, since the author enjoys the wide-ranging freedom ensured by the fictional nature of the genre. What is essential, according to Lukács, is the presentation of human actions in their historical sense and the living manifestation of historical ways of thinking, feeling, and acting.

It is important, however, to highlight the centrality Lukács gives to "fictional means." The historical novel is a variety of "ludic intersubjective feint" (SCHAEFFER 2010, p. 124), a literary fiction that plants its flag in the ground between what happened and what might have happened, using this very imprecision in its own favor. It permits characters who never existed to interact in concrete ways with others who did; this is not a problem for readers who are even minimally familiar with the "rules" of the game. When we allow a story with a historical basis to use such "ludic feint," we accept the terms of 
a tacit agreement woven over the course of many decades, by authors' practices. As Alfred Döblin provocatively suggested, "the historical novel is, in the first place, a novel; in the second place, it isn't history" (in COHN 1999, p. 153).

Even so, the structural coexistence between a narrative's referential and non-referential aspects does signal some sort of "ontological insecurity." Be that as it may, the scales do not quite balance as we read, tending to tilt toward the side of the imaginary. Yes, it is history, but it is fictionalized history, an alternative past, as Lubomir Doležel (2010) puts it. The balance between fact and fiction is not even an ethical and aesthetical goal for the realist historical novel: its distinguishing characteristic is erasure, not the policing of such boundaries. In the end, it is difficult to imagine that a reader of War and Peace might be seriously disturbed to discover that the words of Napoleon to Prince Andrei are not real, or that the portrayal of General Kutuzov exaggerates a bit.

However paradoxical it may seem, the "ontological instability" of the material narrated is more blatant in a novel like War and Peace than in narratives that move away from realistic verisimilitude, such as Kafka's The Metamorphosis or Bulgakov's The Master and Margarita. Everything in the story of Gregor Samsa's vicissitudes is based on necessity; the arbitrariness of the fictional universe becomes clear from the very first line. In War and Peace, on the other hand, fact and fiction are so interwoven that they are, to a point, undistinguishable. This did not escape Alessandro Manzoni's attention, author of $I$ promessi sposi, one of the most noteworthy historical novels of the $19^{\text {th }}$ century:

Some people, however, complain that when in this or that historical novel, in this or that part of a historical novel, the truth is not clearly differentiated from the things that have been made up, and that this causes the novel to fail to achieve what should be one of the primary goals of this type of writing, which is to offer a true representation of history. However, as we stated at the beginning, there are those who argue exactly the opposite. 
They complain that in this or that historical novel, in this or that part of a historical novel, the author clearly expresses the truth that they made something up: something they say destroys the unity essential to this or any other artistic invention (MANZONI 2016).

This passage comes from a 1850 essay. Manzoni defines the historical novel as a "mixed composition of history and invention," a genre based on "inherently contradictory premises"; on the one hand, the desire to present the past in a trustworthy way, and on the other, the tireless quest for aesthetic unity, "an essential condition for this, or any other type of artistic work." This conflict could not be resolved in 1850; the "mixture of history and fiction" had long been consolidated as the defining characteristic of this peculiar genre. It is interesting that Manzoni presupposes complaining critics and readers ("some people complain that in certain historical novels..."), which may help us understand how the historical novel was received during this era. Regardless, both the hybrid qualities of the historical novel (the dual character of historical narrative and imaginative literature) and its vast cognitive potential (the idea that it can be more true than scientific history) were highlighted by men of letters in the first half of the $19^{\text {th }}$ century like Augustin Thierry, who in a critical text even refers to Ivanhoe as "real and truly historical theatre" (JABLONKA 2014, p.59).

However, Lukács, writing in the first half of the $20^{\text {th }}$ century, was not as enthusiastic as Thierry about the historical novel of the present. He argues that it was a stagnant, decadent genre: "Artistically, a decisive rupture has not occurred between the forms and methods of figuration of the modern historical novel" (LUKÁCS 2011, p. 344). The rupture would only happen years later-and in a way that might have driven the Hungarian philosopher into a fury. As I will explain in the next section, the historicity of literary forms, the changes over time-above all starting in the 1960s-would reignite the spark left by Manzoni. This new type of historical novel, written in the last four decades of the $20^{\text {th }}$ century, would contest the "tacit agreement" that 
for nearly two centuries had set the agenda for the production and reception of historical fiction, seeking to face head on the ambivalences Manzoni had identified. This "tacit agreement" granted writers of historical novels wide-ranging freedom in their handling of empirical data. As for readers, they would not worry about small or even large factual or interpretative inaccuracies. The essential was that the narrative recreate the climate of bygone times, and position us as spectators of a here that is now unrecoverable.

\section{Historicity of the Form: Changes in the Historical Novel}

The creative autonomy to give shape to the past-with the use of interior monologues, dialogues, socially representative characters, and the free handling of points of view-grants the authors of historical fiction a vast practical terrain upon which to investigate historicity (ANHEIM and LILTI, 2010). It is undeniable that reading a good historical novel can awaken our sense of fantasy and offers a more humanized understanding of the passage of time, besides stimulating the sensorial experience of the past-what Frank Ankersmit (2010, p. 45) called "an epiphany of reality itself." To put oneself in the place of the other, reenact what has already been lived, inhabit the minds of the dead: these experiments with the "gray areas" of human knowledge, which are practically a novelist's duty, are largely prohibited in admittedly referential genres, like biography and history, both of which are ruled by intersubjective protocols of ethical and scientific validation. But in historical fiction, speculation about consciousness is welcomed. As Hayden White (2014) suggests in The Practical Past, literature tends to direct itself toward aspects of the human experience that "scientific" history does not see itself as qualified to explain. It is precisely these uncertain and difficult positions that historical fiction tries to navigate: the point of view of soldiers (Stendahl's The Charterhouse of Parma and Tolstoy's War and Peace), the mind of perpetrators of violence (Jonathan 
Littell's The Kindly Ones and Bernardo Kucinski's K. Relato de uma busca), the exploration and reenactment of the thought of great historical figures (Marguerite Yourcenar's Memoirs of Hadrian, John Williams's Augustus), the unspeakable aspects of a testimony (W. G. Sebald's Austerlitz and Yannick Haenel's Jan Karski).

Historically speaking, the alliance between historical imagination and literary fiction became more viable as a result of what Catherine Gallagher, in her essay about the consolidation of the modern principle of fictionality, calls the intimate connection between novel and fiction:

[C]andidly and explicitly differentiating their works from the kinds of referentiality proffered by neighboring genres, these writers coaxed their readers to accept the imaginative status of their characters. And yet the same eighteenth-century novelists also seem to have imprisoned and concealed fictionality by locking it inside the confines of the credible. The novel, in short, is said both to have discovered and to have obscured fiction (GALLAGHER 2006, p. 337).

Comparing with other types of realist novels, the hiding of fiction in the historical novel was an even more laborious process, thanks to its dual foundations in history (as discourse and process) and imagination (fictional but also historical), a combination that accentuates the unreal and the alternative in the constructed past. For readers, to become immersed, to suspend disbelief, depends on a continuous negotiation with the referential and non-referential poles of the historical novel-a challenge that bothered Manzoni but at the same time served as fuel for his literature.

Only in the early 1960 s would this issue of dual foundations be consistently addressed by the very form of historical fiction, and not only by critics. The so-called "historiographic metafiction" (HUTCHEON 1991)-also known as the "metahistorical novel" and "postmodern historical novel," depending on which poetic aspects they seek to highlight-rejects the fundamental goal 
of the $19^{\text {th }}$ century historical novel: to relive the past through literature. This goal could only be achieved with high doses of rhetorical illusionism and realist sleight of hand, by creating a "vicarious firsthand experience of living in a certain historical time," as though it were possible to bring the past back to life (COETZEE 1988, p. 3). In contrast, historiographic metafiction sought to make use of the ludic, sometimes ironic, intentional entangling of fact and fiction. The desire to brush history against the grain, to research the inaccessible regions of the past, to fathom the unfathomable through the parodic-but also sublime-rewriting of history are some of the significant features of the new ethos of historical fiction. Seen from this angle, what I called the "ontological instability" of the realist historical novel, as signaled by the hybridization of fiction and historic narrative, is no longer hidden, uncomfortable, or repressed. On the contrary: the form of the novel faces head on this reluctance to fictionalize history. Often, this results in a productive conflict between the "sublime desire" to restore the past in its difference (ELIAS 2001) and recognizing that the fictional universe is sufficient in and of itself, that "there is no outside text." In The Novel Today, an essay that discusses the tense relationship between novel and history, J. M. Coetzee is categorical:

I reiterate the elementary and rather obvious point I am making: that history is not reality; that history is a kind of discourse; that a novel is a kind of discourse, too, but a different kind of discourse; that, inevitably, in our culture, history will, with varying degrees of forcefulness, try to claim primacy, claim to be a master-form of discourse (COETZEE 1988, p. 4).

If, as Hayden White showed in the early 1970s, history and novel are much more similar discursive forms than previously imagined, and if historical discourse "is nothing but a certain kind of story that people agree to tell each other," as Coetzee writes, what sort of uniqueness is left for the historical novel? Can its analysis still be based on the criterion of dual foundations? Fredric Jameson (2013, p. 263) asks whether the 
historical novel is even possible today, since the very notion of historical process has been put in check by critical theory and postmodern fiction. "What kind of History can the contemporary historical novel then be expected to 'make appear'?"

A narrative like J. M. Coetzee's Disgrace (1999) clearly does not look much like a classic historical novel. It is true that the fall into disgrace of Professor David Lurie sheds light on the vicissitudes of recent South African history, of a recent past that is becoming the present in Nelson Mandela's South Africa. However-and I base this on categories the author himself proposed in The Novel Today-Disgrace does not presuppose a relationship of "supplementarity", but rather of "rivalry" between fiction and history. One of Coetzee's main goals with this novel, which has been identified by scholars like David Atwell (2015) and Derek Attridge (2004), was to intervene in debates concerning confession, truth and guilt that, with the organization of the Truth and Reconciliation Commission in the second half of the 1990s, received significant attention from South African intellectuals (SANDERS 2002). Coetzee presents antagonistic versions of the country's past and future-of the daughter Lucy, Petrus, Malanie's father, Farodia Rassolbut always filtered through the morally ambiguous gaze of someone who does not feel comfortable with these new times, David Lurie. Of course, Lurie's tale was not a "trustworthy" translation of the South African political and social situation of the second half of the 1990s. Rather, what is at play in Disgrace is not a documentary account of life post-apartheid, but rather a willingness of being heard in public debates. Not through arguments, as would be the case in an essay, but rather with the resources of literary fiction, of historical fiction: representative situations, polyphonic angulation, and the weaving of a plot through fictional modes.

Tolstoy, in the philosophical digressions that interrupt War and Peace, speculates on the nature of Russian history with a voice that is neither that of his characters nor of the narrator, but rather, perhaps, his own. He hoped to take a 
position in a public debate among philosophers and historians and offer his interpretation of the dynamic of Russian history. ${ }^{1}$ In Coetzee's case, indicating the new ethos of historical fiction, the difference lies in the realization that a novel should operate "in terms of its own procedures and issues in its own conclusions," and not "in terms of the procedures of history and eventuates in conclusions that are checkable by history." Fictional universes do not exist to be confirmed or fact-checked by the historiography, "as a child's schoolwork is checked by a schoolmistress" (COETZEE 1988, p. 3).

If the mixture of historical narrative and fictional invention has not been entirely discredited by historiographic metafiction, it has lost its rhetorical allure, at least as an individualizing characteristic of the historical novel. This was due to the dominant understanding, especially among followers of Hayden White, that history's reality was essentially discursive, and its bases in "the fact" constituted nothing more than a second or third order referencing-not "actual reality," but rather the accepted modes of understanding and representing the past. Besides, the realist novel stagnated in the second half of the $20^{\text {th }}$ century: the most groundbreaking forms of historical fiction began to make extensive use of both illusionist techniques and anti-illusionist procedures (GLYNN 2005). In this historicalliterary context, claiming that a given novel is historical becomes less a taxonomic issue than one of emphasis, since such diverse genres as science fiction, dystopia, and counterfactual novels, along with historiographic metafiction turn their focus to the figuration of time and historicity (JAMESON 2005).

As Dorrit Cohn puts it, "by the same token, I would propose that it is on principle possible to read any novel as a historical novel" (1999, p. 161). This claim signals a major shift in how the historical novel was seen at the end of the $20^{\text {th }}$ century: in contrast to Manzoni and Lukács, Cohn recognizes that referentiality may not even be relevant for most contemporary readers of fiction. Even the slightest hesitation about the pact of reading disappears.
1 - According to Hayden White (2007, p. 43), War and Peace "undermines Western European literary realism by questioning the ideology of the history on which it is based." 


\section{The turn towards referentiality in contemporary narrative}

Recognizing that a novel should operate "in terms of its own procedures"-and that it may act as a rival to historical discourse and not simply complement it-is one of the distinctive characteristics of the metahistorical novel of the final decades of the $20^{\text {th }}$ century. In El entenado, published in 1983, Juan José Saer (2002) starts with an actual historical event: "the arrival of the Spanish conquistador Juan Díaz de Solis at the Río de la Plata in 1516," followed by an attack by indigenous cannibals (ABBATE 2014, p. 15). The only survivor, the cabin boy Francisco del Puerto, is carried off by the indigenous people and spends ten years living among them, before being rescued by travelers. This is what $16^{\text {th }}$-century accounts tell us. The novel is narrated by a cabin boy who faced similar difficulties: he also survives the attack, is captured, and ten years later returns to Europe. At no point does the narrator reveal his name, nor does he need to; we realize that he is not del Puerto, based on the language and the essayistic style. It is impossible not to be reminded of Montaigne or Jean de Lery. But the narrator's speculations carry us to even more unexpected places: the Mythologiques of Lévi-Strauss, and towards Saussure. Pulling the strings from behind the curtain, Saer plays with the arbitrary meaning of def-ghi, a word with innumerable meanings in the indigenous language, a bird with a black beak and yellow and green feathers, an absent or sleeping person, the reflection things make on water, a man who goes on a mission and returns to tell what he saw. And for the readers, a simple alphabetic sequence of letters: $d, e, f, g$, $h, i$.

The corpus of historiographic metafiction, or of postmodern metahistorical novels, was set and studied by authors like Patricia Waugh (1984), Linda Hutcheon (1991), Brian McHale (1987), Ursula K. Heise (1997), Amy J. Elias (2001), Ruth Glynn (2005), Lubomír Doležel (2010), and Maria Valéria Gobbi (2011). The following are a few of the novels commonly 
addressed in these studies: The French's Lieutenant's Woman (John Fowles, 1969), Gravity's Rainbow (Thomas Pynchon, 1973), Terra Nostra (Carlos Fuentes, 1975), The Name of the Rose (Umberto Eco, 1980), Foe (J. M. Coetzee, 1986), Beloved (Toni Morrison, 1987), The History of the Siege of Lisbon (José Saramago, 1989), Possession (A. S. Byatt, 1990), Alias Grace (Margaret Atwood, 1996). I will not revisit them in this and the next section of this article. Rather, my focus will be a new face of the historical novel: a collection of accounts that are distinguished by the "irresistible appeal to the real," a "collective real, which can be called social or historical." (BOUCHERON 2010 , p. 446). I call this a turn towards referentiality, or a referential dominant in contemporary narrative. Published for the most part in the $21^{\text {st }}$ century, these narratives are remote descendants of the realist historical novel (in the mixture of historical narrative and literary figuration). More directly, perhaps more clearly, they are heirs of historiographic metafiction (in their procedures) and of Walsh and Capote's nonfiction novel (in their appeal to truth). One of the clearest indicators of the turn towards referentiality in recent literary works is the portrayal of the narrator's resistance to fiction.

Although they call themselves true stories, these works also claim to be novels (in the subtitle, paratext, essayistic passages, or structural composition), and, although it may sound contradictory, or perhaps because of it, they resort to some extent to the fictionalization of history or real people's biography. This is what happens in Dora Bruder (Patrick Modiano, 1997), Soldados de Salamina (Javier Cercas, 2001), El material humano (Rodrigo Rey Rosa, 2009), Jan Karski (Yannick Haenel, 2009), HHhH (Laurent Binet, 2010), and K. Relato de uma busca (Bernardo Kucinski, 2011). Or even in an unclassifiable book like W. G. Sebald's Austerlitz (2001).

It is also the case for narratives that openly reject fictionality, but not imagination and conjecture, while combining formal characteristics of the historiographic essay with elements of the historical novel. The so-called-many times by the authors 
themselves-non-fiction novels, or "novels without fiction," like Hans Magnus Enzensberger's The Brief Summer of Anarchy (1972) and Hammerstein (2008); Leonardo Sciascia's The Disappearance of Majorana (1975) and 1912+1 (1986); Patrick Deville's Plague and Cholera (2012) and Viva (2014); Javier Cercas's The Impostor (2014) and The Monarch of Shadows (2017); Emmanuel Carrère's Limonov (2011); and Selva Amada's Dead Girls (2014).

Finally, some narratives that are part of the turn towards referentiality take the path of generic indetermination-like Isabela Figueiredo's Caderno de memórias coloniais (2009)even as they share with late $20^{\text {th }}$ and early $21^{\text {st }}$ century novels a series of formal attributes, like the autobiographical tendency and the casting of the writer as one of the characters in the story, often the main character (LADDAGA 2013).

The "appeal to reality" in contemporary literature can only be fully analyzed considering recent transformations in the way time is conceived. Presentism (Hartog), the slow present (Gumbrecht), updatism (Araújo and Pereira), the end of temporality (Jameson), and temporal acceleration (Rosa) are some of the most common-albeit at times contradictorydiagnoses (TURIN 2017). ${ }^{2}$ Since I already addressed this issue in another article (CHARBEL 2016), I would like to proceed in a different direction. What interests me here is to examine how the early $21^{\text {st }}$ century novel appropriates characteristics of both realist historical fiction and the nonfiction novel, placing once again the issue of referentiality on the historical fiction agenda.

\section{The challenge of the nonfiction novel to the historical novel}

The premise of the nonfiction novel, as imagined and practiced between the 1960 s and 1980s by Truman Capote, Rodolpho Walsh, Norman Mailer, Tom Wolfe, and others, was the composition of narratives that were true in content and "literary" in form, combining rigorous research with fictional
2 - In an essay about the figurations of time in recent fiction, Turin $(2017$, p. 58) avoids a direct alignment with these models, refusing to interpret the novels he analyzes as "documents that illustrate some great argument regarding the unity of the period." 
techniques from the realist novel. In an interview with George Plimpton (1966), Truman Capote states that his motivation in writing In Cold Blood (1966) was to understand that journalism and reporting "could be forced to yield a serious new art form: the 'nonfiction novel', as I thought of it." But does the nonfiction novel truly dispense with fiction? To Dorrit Cohn, the phrase "nonfiction novel" serves as an oxymoron:

Closer study would confirm that their fictionalizing devices boil down principally to the consistent application of focalizing technique-sometimes in stream-of-consciousness form-to real-life sports heroes, rock stars, and convicted murderers. In this perspective, biographies that act like novels, far from erasing the borderline between the two genres, actually bring the line that separates them more clearly into view (COHN 1999, p. 29).

In fact, in works like The Executioner's Song (Mailer) and In Cold Blood (Capote), signs of fictionality are everywhere: in the artificial naturality of the dialogues, in the effects of the real, in the omniscient point of view that (at least in In Cold Blood) creates an appearance of objectivity. Truman Capote often said that his method was "immaculately factual." But, as Matinas Suzuki Jr. (2003) has argued, several people mentioned in the book, upon being transformed into characters, questioned "the lack of precision in the transcription of the interviews and the description of their involvement in events." The same holds true for Mailer. Hence Ivan Jablonka's (2014, p. 240) suggestion that the nonfiction novel should be treated, in general, as simply "globally true."

Returning to Döblin's aforementioned maxim, it is possible to state that the nonfiction novel, just like the historical novel, is "first and foremost a novel." However, it undeniably involves a considerable displacement, in that the literary creation intentionally takes the path of referentiality. Although zeal for historicity became an obsession for writers like Scott and Tolstoy, creative freedom, the foundation of the modern theory of fiction, is obvious to readers of historical novels. As Lubomír 
Doležel (2010, p. 84) argues, the "possible worlds" of the historical novel "share the semantic, structural, and pragmatic features of all fictional worlds." However, in the nonfiction novel, the inhibition of fantasy is a requirement: nothing of "merely" plausible situations, or of imaginary characters. At the same time, controversially to be sure, dialogues, internal monologues, and effects of reality are allowed. In the nonfiction novel, "everything is true," except for whatever the author might have made up.

But is it possible to read a novel separating parts that could and could not be proven? Not very. Perhaps it would be more useful to see the oxymoron, the definition by negation-the "non" in "nonfiction"-as less of a barrier than an opportunity for creativity. Here also we have the opportunity to take a new direction. The nonfiction novel appears to place all its bets on one number of the literary wheel: the "surplus value of the real," as Laurent Binet calls it, or "reality hunger," in the words of David Shields (2010). Certain true stories, as long as we know how to catch them, to recognize them, contain "intrinsically novelistic elements," and "often go beyond fiction," Binet argues (2011, p. 83), in an essay significantly titled The Marvelous Real. But how to handle this "surplus value of the real" and grasp what is intrinsically novelistic in reality itself? "It stupefies, it sickens, it infuriates, and finally it is even a kind of embarrassment to one's one meager imagination," wrote Philip Roth (2007, p. $167)$ in the 1960s. How is it possible to arrive at the "hard core" of history without resorting to fiction? Ultimately, as Capote recognizes in his interview with Plimpton, the nonfiction novel wants to be "serious art." And by "serious art," he appears to be saying, "the novel." In order to achieve the aesthetic unity that Manzoni identifies as the "vital condition" of any artistic work, it was necessary to invent, make up, take liberties. But only as much as necessary.

Nevertheless, the novel's detour toward referentiality does not seem to be based on a new "veto of fiction," to use Luiz Costa Lima's term (1989, p. 12). On the contrary. This reversal 
of poles-from non-referentiality to referential dominant-is but one more unexpected facet of the elasticity of the concept (and practice) of fiction, which, by denying itself winds up enriching itself.

One of the most pronounced characteristics of the nonfiction novel is an often-productive uncertainty about the correspondence between the material narrated and what actually happened, or can be verified with some degree of certainty, or at least hope. We believe, yet we doubt, all at the same time-ultimately it is a novel, and we learn to read novels very early in life and to recognize that literary fiction is connected to reality without necessarily reproducing it. In a way, this bears some similarities to autofiction, where the dividing lines between the referential and novelistic pacts are at their blurriest. As Lejeune puts it (2014, p. 94), "almost all autofiction is read as autobiography," a formulation that points out to something stimulating in this awkward situation. In nonfiction novels, we can presume that they might be simultaneously read as novels and as reports, at times like biographies-a sign that the reading contract is not exempt from ambivalence. Historical novels that make the turn towards referentiality-but not nonfiction novels-also encourage an analogous lack of certainty, except that instead of hiding it, like realist historical fiction and the nonfiction novel do, novels like Soldados de Salamina, El material humano, and $\mathrm{HHhH}$ (stories that are at the same time historical, biographical, and autofictional), choose to enact their own ethical and epistemological "embarrassments".

Thus, we now have novels that to a great extent are successors of the nonfiction novel: in their aspirations to trustworthiness, in the high level of formal investment, in the desire to achieve a "faction," that is, "a disorienting contraction of fiction and fact," as Javier Cercas calls it (2016, p. 43). "Faction" is disorienting because "all fiction is a mixture of fiction and fact, and pure fiction, without the fuel of the real, is simple abstraction." But they also share with other 
varieties of the novel several formal characteristics: active narrators, filled with uncertainty, who exhibit an investigative force and the difficulties of the writing process, along with "ways of confessing, the revealing of personal circumstances, the gestures and disguises of the great theatre of its own presentation" (LADDAGA 2013, p. 33).

\section{Warnings of Fictionality: Attempts to Reshape the Historical Novel}

El material humano (2009), by the Guatemalan author Rodrigo Rey Rosa, opens with a warning to the reader:

Though it may not seem to be though it may not want to seem to be, this is a work of fiction.

K. Relato de uma busca (2011), by Brazilian writer Bernardo Kucinski, begins with a similar note:

Dear Reader:

Everything in this book is invented, but almost everything happened.

B. Kucinski

French writer Yannick Haenel's Jan Karski (2009) also starts with an explanatory note that is a little longer and perhaps a bit too didactic:

The words spoken by Jan Karski in Part One come from his interview with Claude Lanzmann in Shoah.

Part Two is a summary of Jan Karski's book Story of a Secret State $[\ldots]$

Part Three is fictional. It is based on certain aspects of Jan Karski's life, which I have gathered from, among other sources, Karski, How One Man Tried to Stop the Holocaust by E. Thomas Wood and Stanislaw M. Jandowski (John Wiley \& Sons, New York, 
1994). But the situations, words and thoughts I attribute to Jan Karski are pure inventions.

These are three works written in three different languages, published over a very short span of time (2009-2011), and which open with a sort of warning of fictionality. Why would preambles like these be necessary in the $21^{\text {st }}$ century, analogous to-but in reverse from-the $18^{\text {th }}$ century novels that claimed to be "true stories"? Although they have diverse features, these books do share some characteristics: they are literary narratives that exhibit the turn towards referentiality, but that invoke the tradition of the novel and resort to fantasy and fictionalization in order to achieve a biographical reconstruction and explain the recent past. Considering the close relationship between novel and fiction, what use might warnings like these have for telling a story efficiently? In the nonfiction novel, the goal was to show that it is a novel, but it is all true. Here we have a reversal of poles: it is essentially true, but it is also a novel.

The initial warning of El material humano, as Luciene Azevedo has shown (2019, p. 338), seems to express the "paradox between something that wants but at the same time does not want to look like fiction." Rey Rosa writes a novel that looks like a document, characterized by a certain fetishization of the archive, mixing passages from diaries and notebooks with police records, transcriptions of investigations, quotes from letters, emails. Moreover, the very nature of the material the narrator claims to have discovered in the archive of the Guatemalan National Police-which documents political disappearances, torture, kidnappings, coups, and state terrorism-charms readers and attracts them toward the orbit of the "marvelous real," of a reality that "dumbfounds, sickens, enrages." Even so, the warning continues pounding like a hammer on the reader's head (at least for me) page after page, provoking the question: is this a non-fictional narrative, or a hyperrealist form of literary verisimilitude? 
In $K$, the warning of fictionality appears to have a different function. We are told in the paratext of the disappearance of Ana Rosa Kucinski, the author's sister, kidnapped and killed in 1974 by Brazil's military dictatorship. Like in El material humano, the author commits himself to making his story look like a document. We read letters from A. (the disappeared sister), reports from the state security services, witness statements, the despicable minutes from the meeting that decided to fire A. from her job while her whereabouts were still unknown. However, in an important shift, $K$ shows a formal investment in an impersonal tone: most of the narrative is soberly written in third person, reminiscent of Kafka (the most obvious intertext), and of the style of focalization employed by Coetzee (a reader of Kafka) in Life \& Times of Michael $K$ and Disgrace. The focus shifts back and forth between $K$. , the father searching for his disappeared daughter, and A.'s brother, the main narrator. I say "main" because other characters eventually also come to occupy this position. On these occasions Kucinski opts for a naturalist writing style, reminiscent of 1970 s urban literature, resembling Rubem Fonseca-especially in the dialogues between agents of the security services and in the interior monologues of the torturers.

Everything in this book is invented. How could it be otherwise? After all, we are witnessing the "transcription of history," the literary transposition of experience, and, above all, the fictional exploration of the "limits of what can be said" (BOUJU 2006, p. 20), like in the imaginary and disquieting reflections of torturers. Simultaneously, it is clear to any reader with even a passing familiarity with recent Brazilian history that almost everything happened; the material is mostly verifiable by historical memory and research and subject to disputes between divergent points of view.

The warnings of fictionality in El material humano and $K$ are a far cry from the didactic tone of the opening lines of Jan Karski. The point is not to instruct the reader on how to read the book, to set an agenda for them, or to clearly separate fact 
from fiction, but rather to produce incongruity, to stimulate the reader to simultaneously believe and doubt what they read. Once again at issue, after the postmodern interregnum, is the hybrid nature of the relationship between historical account and fictional invention, but with the appearance and procedures of late $20^{\text {th- }}$ and early $21^{\text {st }}$-century narrative (collage, polyphony, self-reflexiveness, fragment, intertext, autofiction). Thus, novels like El material humano and $K$-alongside many of the works that form the corpus of nonfictional or referential literary narratives-can be read as post-autonomous historical novels (LUDMER 2010); the centripetal nature of the real and the desire to account for the past's difference are both clear, even as they employ fiction while denying it. It is also possible to observe an important difference from the metahistorical novels of the 1980s and 1990s, which I briefly addressed above. The new forms of the historical novel reject the idea that history is simply "a type of story that people agree to tell each other," a sui generis type of fictional discourse. Of course, this does not mean that it turns its back on the procedures of postmodern fiction, to throw the baby out with the bathwater. $K$ and $E I$ material humano use parody (the emulation of the language of official documents) as much as intertext (direct or veiled references to writers like Borges, in Rey Rosa's book, and Kafka, in Kucinski's). And novels like $\mathrm{HHhH}$ (Laurent Binet) and Soldados de Salamina (Javier Cercas) can be seen as ironic, insofar as they reject fiction by resorting to fiction, thus encouraging the stimulating "paradox of nonfiction fiction" (AZEVEDO 2019, p. 339).

As such, I would like to briefly comment on the alert of fictionality at the beginning of Jan Karski. Yannick Haenel is an example of a contemporary novelist who takes the risk of using "other techniques of referentiality to continue creating fiction" (AZEVEDO 2019, p. 335). The novel-if we can even call it that; it is a borderline case-has a simple structure, and it is a predominantly referential account. As we read in the explanatory note, the first chapter glosses over the appearance of Jan Karski, "ex-messenger of the Polish government in exile," 
in Claude Lanzmann's documentary Shoah. Haenel describes Karski's reactions, the changes in his appearance, his ticks, and transcribes many of the words he spoke in front of cameras, with particular attention to the message he was to send on his last mission as envoy to the West, in 1942: the news of the extermination of the Jews, especially the horrors of the Warsaw ghetto.

The second chapter, in Haenel's words, "is a summary of Jan Karski's book," History of a Secret State, published in 1944, during the war. However, more than a synthesis, it involves a process of rewriting and of biographical interpretation. Haenel depicts decisive moments in Karski's life, like his visit to the ghetto. The third chapter, the longest, is a fiction. Haenel bases his account on a well-known biography of Karski, especially the chapter about his meeting with Franklin Roosevelt. However, he emphasizes that "the scenes, sentences, and thoughts attributed to Jan Karski were imagined by me." In summary, the attempt to retell-and give meaning to-Karski's supposedly frustrating meeting with the U.S. president constitutes a free exercise in historical imagination. Roosevelt's character is unable to pay attention, as he yawns while staring at his secretary's legs. He is uninterested in Karski:

The young woman took notes, but Roosevelt said nothing. He had unbuttoned his jacket and slumped comfortably back into his armchair. I think he was digesting his meal. I said to myself: Franklin Roosevelt is a man who is digesting-he was in the process of digesting the extermination of Europe's Jews. And then, when I repeated in front of him the message from the two men in the Warsaw ghetto, when I relayed their demands about the bombing of German cities, Roosevelt slowly opened his mouth. I thought that his reaction was going to be terrible, but it was not. He said nothing: his mouth remained a little twisted, and then he stifled a yawn (HAENEL 2013, p. 114-115).

This portrayal of Roosevelt angered Claude Lanzmann, who wrote a devastating review for the magazine Les temps modernes, accusing Jan Karski of being a "false novel," a novel 
that "deliberately falsifies history." Lanzmann (2010) argues that the available historical evidence contradicts Haenel's version by demonstrating Roosevelt's interest in Karski. Besides, he claims, there were no secretaries in the Oval Office that night. And more than just containing factual errors, Lanzmann continues, the entire portrayal of Karski is "hateful and vulgar," "sadly linear." Finally, Lanzmann accuses Haenel of plagiarism and "parasitism" "for devoting the first part of his novel to a description, of sorts, of Lanzmann's interview with Karski in Shoah, and for lifting entire passages from the film's dialogue without receiving the filmmaker's permission" (GOLSAN 2010, p. 82). Other French intellectuals, like historian Annette Wierviorka, joined the fray. She disputes two points of view of "Karski the character" that, she claims, could never have been attributed to the "real Karski": the relativization of Polish antisemitism and the accusation that the Allies were complicit with the Holocaust.

Haenel's response is significant: claiming that Jan Karski is a false novel is the same as saying that the novel, in and of itself, is "the discourse of the false." In fact, as Richard Golsan (2010, p. 87) suggests in an article about the Karski affair, Haenel's book takes several liberties concerning what is known, what we can verify, about the life of this figure of the Polish resistance, not only concerning the trip to Washington, but above all "the historical and even ideological outlook of the real-life Karski." This should not come as a shock: after all, this is historical fiction, as Haenel makes a point of stating on the first page. Thus, a commitment to factual truth, with complete faithfulness to what really happened, should not be expected to begin with. But it was. And this perhaps indicates that something in the pact of reading does not work well. Thus, even with the alert of fictionality, referentiality winds up prevailing, and the liberties Haenel takes, at least for some readers, are disconcerting, or even reprehensible. Interpreted as forgeries, as lies, these liberties consign fiction to its undesirable other: fraud, deception, sham. 
The issue of the pact of reading is crucial. In $\mathrm{HHhH}$, Laurent Binet (2013) depicts a narrator concerned about how the book he is writing will be received by the public. After reading the first pages of the novel, his friend Fabrice praises the chapter that describes the Night of the Long Knives. The narrator is flattered but suspects he has been misunderstood. "Did you know that every telephone call [in the book] corresponds to an actual event? I could reveal all the names, if I wanted." Fabrice, surprised, answers that he thought it was all made up. "Absolutely not, it's all true," replies the narrator. And he thinks to himself, "'Damnit, it still hasn't worked!' I should have been clearer about the narrative pact." Even after having offered a warning about the fictionality of his portrayal of Karski, it is possible that Haenel, like Binet's narrator, could have been more precise. It is insufficient to announce what you are going to do: it is necessary to make a deal with the readers, who learned only with great difficulty two centuries ago to read historical novels-and from one moment to the next are asked to simply unlearn what they know.

\section{REFERENCE}

ABBATE, Florencia. El espesor del presente. Tiempo e historia en las novelas de Juan José Saer. Villa María: Eduvim, 2014.

ANHEIM, Étienne; LILTI, Antoine. Savoirs de la littérature. Annales HSS, v. 65, n. 2, 2010, p. 253-260. Available at: https://doi.org/10.1017/S0395264900038518. Accessed on: 29 jun. 2019.

ANKERSMIT, Frank. Truth in History and Literature. Narrative, v. 18, n. 1,2010, p. 29-50. Available at: https:// www.jstor.org/stable/25609383. Accessed on: 29 jun. 2019. 
ATTRIDGE, Derek. J. M. Coetzee and the Ethics of

Reading. Chicago and London: The University of Chicago Press, 2004.

ATTWELL, David. J. M. Coetzee and the Life of Writing. New York and London: Viking, 2015.

AZEVEDO, Luciene. Saindo da ficção: narrativas não literárias. Caracol, n. 17, 2019, p. 329-345. Available at: $\quad$ https://doi.org/10.11606/issn.2317-9651.v0i17p329-345. Accessed on: 29 jun. 2019.

BINET, Laurent. Le merveilleux réel. Le débat, 165, maiaoût, 2011, p. 80-85.

BINET, Laurent. HHhH. Trans. Sam Taylor. New York: Picador, 2013.

BOUCHERON, Patrick. "Toute littérature est assaut contre la frontière". Note sur les embarrass historiens d'une reentrée littéraire. Annales HSS, v. 65, n. 2, 2010, p. 441467. Available at: https://www.jstor.org/stable/40929992. Accessed on: 29 jun. 2019.

BOUJU, Emmanuel. La transcription de I'histoire. Essai sur le roman européen de la fin du XXe siècle. Rennes: Presses Universitaires de Rennes, 2006.

CAPOTE, Truman. In Cold Blood. New York: Random House, 1966.

CERCAS, Javier. El punto ciego. Buenos Aires: Random House, 2016.

CHARBEL, Felipe. A ficção histórica e as transformações do romance contemporâneo. In: CHARBEL, Felipe; SILVA MELLO, Luiza; GUSMÃO, Henrique (org.). As formas do romance. Estudos sobre a historicidade da literatura. Rio de Janeiro: Ponteio, 2016. 
COETZEE, J. M. The Novel Today. Upstream, v. 6, n. 1, 1988.

COETZEE, J. M. Disgrace. London: Secker \& Warburg, 1999.

COHN, Dorrit. The Distinction of Fiction. Baltimore and London: The John Hopkins University Press, 1999.

COSTA LIMA, Luiz. O controle do imaginário. Rio de Janeiro: Forense, 1989.

DOLEZEL, Lubomir. Possible Worlds of Fiction and History. Baltimore: The John Hopkins University Press, 2010.

ELIAS, A. J. Sublime desire: History and Post-1960's Fiction. Baltimore: John Hopkins University Press, 2001.

GALLAGHER, Catherine. The Rise of Fictionality. In: MORETTI, Franco (org.). The Novel. Volume I, History, Geography and Culture. Princeton and Oxford: Princeton University Press, 2006.

GLYNN, Ruth. Contesting the Monument. The AntiIllusionist Italian Historical Novel. Leeds: Northern University Press, 2005.

GOBBI, Maria Valéria Zamboni. A ficcionalização da História. Mito e paródia na narrativa portuguesa contemporânea. São Paulo: Editora Unesp, 2011.

GOLSAN, Richard. L'Affaire Karski: Fiction, History, Memory Unreconciled. L'Esprit Créateur, v. 50, n. 4, 2010, p. 81-96. Available at: https://www.jstor.org/stable/26289680. Accessed on: 29 jun. 2019.

HAENEL, Yannick. Jan Karski. Paris: Gallimard, 2009. 
HAENEL, Yannick. The Messenger. Trans. Ian Monk. Berkeley: Counterpoint, 2013.

HEISE, Ursula K. Chronoschisms: Time, Narrative, and Postmodernism. Cambridge: Cambridge University Press, 1997.

HELLER, Agnes. The Contemporary Historical Novel. Thesis Eleven, v. 106, n. 1, 2011, p. 88-97. Available at: https://doi.org/10.1177/0725513611407448. Accessed on: 29 jun. 2019.

HUTCHEON, Linda. A poética do pós-modernismo. Trad. Ricardo Cruz. Rio de Janeiro: Imago, 1991.

ISER, Wolfgang. O fictício e o imaginário. Trad. Johannes Kretschmer. Rio de Janeiro: EdUERJ, 1996.

JABLONKA, Ivan. La historia es una literatura contemporánea. Manifiesto por las ciencias sociales. Trad. Horacio Pons. Mexico: Fondo de Cultura Económica, 2014.

JAMESON, Fredric. Archaeologies of the Future. The Desire Called Utopia and Other Science Fictions. London and New York: Verso, 2005.

JAMESON, Fredric. The Antinomies of Realism. London and New York: Verso, 2013.

KUCINSKI, Bernardo. K. Relato de uma busca. São Paulo: Cosac Naif, 2014.

LANZMANN, Claude. Jan Karski de Yannick Haenel: un faux roman. Les temps modernes, no 657, janvier-mars, 2010.

LADDAGA, Reinaldo. Estética de laboratório. Trad. Magda Lopes. São Paulo: Martins Fontes, 2013. 
LEJEUNE, Philippe. O pacto autobiográfico. De Rousseau à Internet. Trad. Jovita Maria Noronha e Maria Inês Guedes. Belo Horizonte: Editora da UFMG, 2014.

LUDMER, Josefina. Literaturas pós-autônomas. Trad. Flávia Cera. Sopro, n. 20, jan. 2010.

LUKÁCS, Györg. O romance histórico. Trad. Rubens Enderle. São Paulo: Boitempo, 2011.

MANZONI, Alessandro. Del romanzo e, in genere, de' componimenti misti di storia e d'invenzione. CreateSpace Independent Publishing Platform, 2016.

MCHALE, Brian. Post-modernist Fiction. London and New York: Routledge, 1987.

PLIMPTON, George. The Story Behind a Nonfiction Novel. The New York Times, 16 jan. 1966.

REY ROSA, Rodrigo. El material humano. Barcelona: Anagrama, 2009.

REY ROSA, Rodrigo. Human Matter. Trans. Eduardo Aparicio. Austin: University of Texas Press, 2011.

ROTH, Philip. Writing American Fiction. In: ROTH, Philip. Reading Myself and Others. London: The Random House, 2007.

SAER, Juan José. O enteado. Trad. José Feres Sabino. São Paulo: Iluminuras, 2002.

SANDERS, Mark. Complicities. The Intellectual and Apartheid. Durham and London: Duke University Press, 2002.

SCHAEFFER, Jean-Marie. Why Fiction? Lincoln and London: University of Nebraska Press, 2010. 
SHIELDS, David. Reality Hunger. A Manifesto. New York: Alfred A. Knopf, 2010.

SUZUKI JR., Matinas. Nem tudo é verdade, apesar de verdadeiro. In: SUZUKI JR., Matinas. A sangue frio. São Paulo: Companhia das Letras, 2003.

TURIN, Rodrigo. A polifonia do tempo: ficção, trauma e aceleração no Brasil contemporâneo. ArtCultura, v. 19, n. 35, 2017, p. 55-70. Available at https://doi.org/10.14393/ ArtC-V19n35-2017-2-05. Accessed on: 29 jun. 2019.

WAUGH, Patricia. Metafiction. New York and London: Methuen, 1984.

WHITE, Hayden. War and Peace. Against Historical Realism. In: WANG, Q. Edward e FILLAFER, Franz (org.). The Many Faces of Clio. Cross-cultural Approaches to Historiography. New York and Oxford: Berghahn Books, 2007.

WHITE, Hayden. The Practical Past. Evanston: Northwestern University Press, 2014.

\section{AUTHOR NOTE}

\section{Felipe Charbel}

Universidade Federal do Rio de Janeiro - Rio de Janeiro - Rio de Janeiro - Brasil

\section{CORRESPONDENCE ADDRESS}

\section{Felie Charbel}

Universidade Federal do Rio de Janeiro, Instituto de História.

Largo de São Francisco de Paula, 1 - Centro - 22051-070 - Rio de Janeiro, RJ - Brasil

\section{FUNDING}

This article is the result of a research project financed by the Conselho Nacional de Desenvolvimento Científico e Tecnológico (CNPq) and Research Productivity Fellowship/Humanities Competition.

Copyright

2020 História da Historiografia: International Journal of Theory and History of Historiography. This is an Open Access article distributed under the terms of the Creative Commons License AttributionNonCommercialNoDerivatives $\quad 4.0$ International License.

Nenhum conflito de interesse declarado. 